Original paper

DOI: 10.2478/agri-2021-0008

\title{
GRAIN AND OIL YIELDS OF SAFFLOWER (CARTHAMUS TINCTORIUS L.) AFFECTED BY WATER DEFICIT AND GROWTH REGULATORS
}

\author{
ROGHIYEH FARZI-AMINABAD, KAZEM GHASSEMI-GOLEZANI*, \\ SAFAR NASRULLAHZADEH
}

University of Tabriz, Tabriz, Iran

\begin{abstract}
Farzi-Aminabad, R., Ghassemi-Golezani, K. and Nasrullahzadeh, S. (2021). Grain and oil yields of safflower (Carthamus
\end{abstract} tinctorius L.) affected by water deficit and growth regulators. Agriculture (Polnohospodárstvo), 67(2), 87-94.

In order to evaluate the effects of growth regulators on yield parameters and oil content of safflower (Carthamus tinctorius L.), a field experiment was conducted under different irrigation intervals in 2019. All plots were irrigated regularly until the seedling establishment and thereafter irrigation intervals were applied after 70, 100, 130, and $160 \mathrm{~mm}$ evaporation from class A pan, as normal irrigation and mild, moderate, and severe water deficits, respectively. Foliar sprays of water (control), putrescine $(60 \mu \mathrm{g} / \mathrm{L})$, and 24 -epibrassinolide $(25 \mu \mathrm{g} / \mathrm{L})$ at a rate of $1,000 \mathrm{~L} /$ ha were applied slightly before flowering. The results revealed that means of plant biomass, grains per capitol, grains per plant, grain yield, harvest index, oil percentage, and yield were decreased under limited irrigations, but 1,000-seeds weight was only reduced under severe water deficit. However, foliar sprays of growth regulators, particularly putrescine, increased grains per plant, grain yield, and harvest index, leading to an improvement in oil yield per unit area under different levels of water supply. These results suggest that foliar application of putrescine is a superior treatment for improving the productivity of safflower plants under normal and stressful conditions.

Key words: drought stress, harvest index, epi-brasinollide, plant biomass, putrescine

Safflower (Carthamus tinctorius L.) is originated from south Asia and is cultivated in the same regions that favor the growth and development of wheat and barley. It is undoubtedly a crop with great potential and compatibility to be grown in a wide range of environments (Gilbert et al. 2008). Nevertheless, the productivity of this crop could be limited by abiotic stresses such as water deficit. Drought is one of the most detrimental environmental stress for plant growth and development (Krouma et al. 2015), that can affect different physiological and biochemical processes in plants (Mohammadi et al. 2018a). Water deficit can naturally occur in the field when water availability is less than evapotranspiration demand. This can cause a decline in carbon assimilation, cell growth, and tissue expansion. Many genes, enzymes, hormones, and metabolites are involved in each of these processes (Skirycz \& Inze 2010).

Putrescine as a polyamine is involved in scavenging of the free radicals and regulating osmotic potential under drought stress (Gupta et al. 2013; Li et al. 2014). It can stimulate plant growth by acting as a nitrogen source and influencing cell division and development (Kandil et al. 2011). There is also a relationship between brassinosteroids (BRs) concentration and oxidative stress in plants (Bajguz

Roghiyeh Farzi-Aminabad, MSc Student, Department of Ecophysiology, Faculty of Agriculture, University of Tabriz, Tabriz, Iran

Kazem Ghassemi-Golezani, Prof. (*Corresponding Author), Department of Ecophysiology, Faculty of Agriculture, University of Tabriz, Tabriz, Iran. E-mail: golezani@gmail.com

Safar Nasrullahzadeh, Assoc. Prof., Department of Ecophysiology, Faculty of Agriculture, University of Tabriz, Tabriz, Iran

(C) 2021 Authors. This is an open access article licensed under the Creative Commons Attribution-NonComercial-NoDerivs License

(http://creativecommons.org/licenses/by-nc-nd/4.0/). 
\& Hayat 2009). Some reports revealed that exogenous application of BRs such as 24-epibrassinolide alter the activities of antioxidant enzymes such as catalase, superoxide dismutase, ascorbate peroxidase, and glutathione peroxidase under stressful conditions (Ozdemir et al. 2004). These are a group of steroidal growth regulators (Bajguz \& Piotrowska-Niczyporuk 2014) influencing stress tolerance, seed germination, growth, and senescence of plants (Rao et al. 2002). This research was aimed to assess the impact of exogenously applied putrescine and 24-epibrassinolide on reducing the harmful effects of drought stress on field performance of safflower plants.

\section{MATERIAL AND METHODS}

A field experiment was conducted in 2019 at the Research Farm of the University of Tabriz in Iran, located at $38.05^{\circ} \mathrm{N}, 46.17^{\circ} \mathrm{E}$ with an altitude of $1,360 \mathrm{~m}$ above sea level, annual rainfall about $263 \mathrm{~mm}$, and mean annual temperature of $13.5^{\circ} \mathrm{C}$. The annual rainfall during 2017-2020 ranged from $200.87 \mathrm{~mm}$ up to $380.75 \mathrm{~mm}$. The total rainfall during experimentation was about $7 \mathrm{~mm}$ and the mean temperature ranged $15.7-29.8^{\circ} \mathrm{C}$. The physical and chemical properties of the farm soil are presented in Table 1.

The experiment was laid out as a split plot based on randomized complete block design in three replicates with irrigation intervals $\left(\mathrm{I}_{1}, \mathrm{I}_{2}, \mathrm{I}_{3}\right.$, and $\mathrm{I}_{4}$ : irrigation after $70,100,130$, and $160 \mathrm{~mm}$ evaporation from class A pan, for normal irrigation and mild, moderate and severe water deficits, respectively) in main plots and foliar spray of growth regulators in sub-plots. Each plot consisted of 6 rows with $5 \mathrm{~m}$ length, spaced $25 \mathrm{~cm}$ apart. The seeds were sown manually on $14^{\text {th }}$ May 2019 at a depth of 3-4 cm, with a distance of $10 \mathrm{~cm}$ on the rows to achieve a density of 40 plants $/ \mathrm{m}^{2}$. All plots were irrigated after sowing. Subsequent irrigations were carried out according to the treatments up to field capacity (FC). Weeds were controlled by hand during plant growth and development. Variants of foliar sprays of growth regulators: water (control), putrescine $(60 \mu \mathrm{g} / \mathrm{L})$, and 24-epibrassinolide $(25 \mu \mathrm{g} / \mathrm{L})$ at a solution rate of $1,000 \mathrm{~L} / \mathrm{ha}$ were applied on plants slightly before flowering. At maturity, plants in $1 \mathrm{~m}^{2}$ of the middle part of each plot were harvested and the number of grains per capitol, number of grains per plant, 1,000-seeds weight, and grain yield were determined. Aboveground biomass was oven-dried at $75^{\circ} \mathrm{C}$ for 48 hours and then, plant biomass per unit area was recorded. Harvest index was calculated as:

Harvest index $=($ grain yield $/$ plant biomass $) \times 100$

A Soxhlet extractor was used to extract oil according to the AOCS method (1993). Initially, 5 grams of grains from each plot were crushed by a milling machine. The filter papers were cut into bottom tubes and the shredded samples were poured into paper tubes and placed inside the Soxhlet exactor. $200 \mathrm{ml}$ of petroleum ether was poured into a round bottom flask and a few pieces of boiling stone were thrown into it. The Soxhlet extractor and refrigerant were then installed on the flask. Then the faucet was turned on to allow water to flow into the refrigerant. As soon as the first drop of solvent was distilled and dripped from the refrigerant, the time was recorded. Extraction was continued for 5 hours. The heat source was then turned off to cool the system, and the vapor was cooled to a liquid. After that, the flask was removed from the clamp.

$\mathrm{T}$ a $\mathrm{b} 1 \mathrm{e} 1$

Physical and chemical properties of farm soil

\begin{tabular}{|c|c|c|c|c|c|c|c|c|c|c|c|c|c|c|c|}
\hline $\begin{array}{l}\text { Depth } \\
{[\mathrm{cm}]}\end{array}$ & $\mathrm{pH}$ & $\begin{array}{l}\text { Electrical } \\
\text { conductivity }\end{array}$ & $\begin{array}{c}\text { Total } \\
\text { neutralizing } \\
\text { material [\%] }\end{array}$ & $\begin{array}{c}\text { Organic } \\
\text { carbon } \\
{[\%]}\end{array}$ & $\begin{array}{c}\text { Total } \\
\text { nitrogen } \\
{[\%]}\end{array}$ & \multicolumn{6}{|c|}{$\begin{array}{c}\text { Absorbable elements } \\
{[\mathrm{mg} / \mathrm{L}]}\end{array}$} & \multicolumn{3}{|c|}{$\begin{array}{l}\text { Mineral } \\
\text { components of } \\
\text { soil }[\%]\end{array}$} & $\begin{array}{l}\text { Soil } \\
\text { texture }\end{array}$ \\
\hline $0-30$ & 8.0 & 2.92 & 10.5 & 0.37 & 0.04 & $\begin{array}{c}\mathrm{P} \\
4.9\end{array}$ & $\begin{array}{c}\mathrm{K} \\
255\end{array}$ & $\begin{array}{l}\mathrm{Ca} \\
0.76\end{array}$ & $\begin{array}{l}\mathrm{Fe} \\
2.6\end{array}$ & $\begin{array}{r}\mathrm{Zn} \\
0.92\end{array}$ & $\begin{array}{l}\mathrm{Mn} \\
3.34\end{array}$ & $\begin{array}{c}\text { Clay } \\
12\end{array}$ & $\begin{array}{r}\text { Silt } \\
14\end{array}$ & $\begin{array}{c}\text { Sand } \\
74\end{array}$ & $\begin{array}{l}\text { Sandy } \\
\text { loam }\end{array}$ \\
\hline
\end{tabular}


The samples were then weighed and oil percentage and yield were determined.

The data were analyzed using the model of two-factorial analysis of variance (irrigation interval, growth regulators), by MSTATC software; and the means were compared by Duncan multiple range test at $P \leq 0.05$. The Excel software was used to draw figures.

\section{RESULTS AND DISCUSSION}

Analysis of variance (Table 2) showed that water deficit and growth regulators had significant effects on plant biomass, number of grains per capitol, number of grains per plant, 1,000-seeds weight, grain yield, harvest index, and oil yield. The oil percentage was also significantly affected by water limitation. The interaction of irrigation $\times$ growth regulator was significant for grains per plant, grain yield, harvest index, and oil yield.

The plant biomass was deceased with increasing irrigation intervals (Table 3). Foliar spray of growth regulators increased plant biomass of safflower, with no significant difference between putrescine and 24-epibrassinolide treated plants (Table 3). As determined by Ghassemi-Golezani and Afkhami (2018), plant biomass reduction in water stressed plants is the consequence of decreasing cell growth, leaf area, and intensity of photosynthesis. Water deficit decreases the water potential of plants, leading to stomata closure and reduction in photosynthesis rate, leaf growth (Ozturk 1999), and plant biomass. Reduction in plant biomass resulted in decreasing the number of grains per plant, 1,000-seeds weight, and consequently, grain yield and harvest index of milk thistle (Ghassemi-Golezani et al. 2017). Decreasing plant biomass by water limitation has also been observed in sesame (Eskandari et al. 2009) plants. The increment of plant biomass in putrescine-treated safflower plants was related to further expansion and persistence of leaf area, providing sufficient photosynthates for plant growth (Emadi et al. 2013). Application of brassinolide can also enhance plant dry matter through increasing relative water content, and chlorophyll content in soybean (Zhang et al. 2008).

The number of grains per capitol was decreased under water deficit, with no significant differences among limited irrigations (Table 3). The highest number of grains per capitol was recorded for putrescine treated plants, with no significant difference between growth regulators (Table 3). Foliar application of brassinolide also increased the number of grains per spike of wheat under normal and limited irrigations (Dehghan et al. 2017). This growth regulator increased the number of flowers and grain yield in mung bean, due to the prevention of flower

$\mathrm{T}$ a b 1 e 2

Analysis of variance (mean squares) of grain yield and yield components in safflower affected by water deficit and growth regulators

\begin{tabular}{|l|c|r|r|r|r|r|r|r|r|}
\hline Source of variation & df & $\begin{array}{c}\text { Plant } \\
\text { biomass }\end{array}$ & $\begin{array}{c}\text { Grains per } \\
\text { capitol }\end{array}$ & $\begin{array}{c}\text { Grains } \\
\text { per } \\
\text { plant }\end{array}$ & $\begin{array}{c}1,000 \\
\text { seeds } \\
\text { weight }\end{array}$ & $\begin{array}{c}\text { Grain } \\
\text { yield }\end{array}$ & $\begin{array}{c}\text { Harvest } \\
\text { index }\end{array}$ & $\begin{array}{c}\text { Oil } \\
\text { percentage }\end{array}$ & $\begin{array}{c}\text { Oil } \\
\text { yield }\end{array}$ \\
\hline Replication & 2 & 4954.40 & 91.29 & 799.36 & 5.04 & 30.99 & 4.090 & 0.029 & 2.73 \\
Irrigation (I) & 3 & $117,307.33^{++}$ & $77.69^{++}$ & $19,586.49^{++}$ & $5.70^{+}$ & $29,794.93^{++}$ & $453.57^{++}$ & $30.20^{++}$ & $3,191.49^{++}$ \\
$\mathrm{E}_{\mathrm{a}}$ & 6 & $1,002.59$ & 15.78 & 460.47 & 0.78 & 322.08 & 15.76 & 0.19 & 19.74 \\
Regulators (R) & 2 & $26,393.44^{++}$ & $303.32^{++}$ & $11,587.68^{++}$ & $4.36^{+}$ & $15,479.56^{++}$ & $70.14^{++}$ & $0.017^{\mathrm{ns}}$ & $1,147.94^{++}$ \\
$\mathrm{I} \times \mathrm{R}$ & 6 & $142.10^{\text {ns }}$ & $3.28^{\mathrm{ns}}$ & $364.39^{+}$ & $0.90^{\text {ns }}$ & $504.02^{++}$ & $9.35^{+}$ & $0.033^{\mathrm{ns}}$ & $56.80^{++}$ \\
$\mathrm{E}_{\mathrm{b}}$ & 16 & 362.65 & 4.17 & 112.75 & 0.80 & 116.38 & 2.26 & 0.033 & 10.63 \\
\hline $\mathrm{CV}[\%]$ & - & 3.02 & 7.12 & 6.29 & 3.23 & 5.79 & 2.67 & 0.68 & 6.47 \\
\hline
\end{tabular}

$\mathrm{E}_{\mathrm{a}}, \mathrm{E}_{\mathrm{b}}$ - errors for main and sub-plots, respectively; $\mathrm{CV}$ - coefficient of variation; $\mathrm{df}$ - degrees of freedom

$\stackrel{+}{+}{ }^{++}$and ${ }^{n s}-$ significant at $p \leq 0.05, p \leq 0.01$ and no significant (F-test), respectively 
abortion and higher content of phenolic compounds (Ananthi et al. 2013). Foliar application of brassinolide increases the transport of nutrients within the plant (Fuji et al. 1991). Brassinolide is involved in physiological and metabolic processes such as photosynthesis, nucleic acid synthesis, proline accumulation, and protein production, as well as in the gene transcription and translation, leading to an increase in protein content, including enzymes (Anjum et al. 2011).

The number of grains per plant significantly decreased with increasing irrigation interval, without significant differences between mild and moderate stress. Foliar sprays of growth regulators led to a significant increase in the number of grains per plant at all levels of water stress. A significantly higher value was recorded in the variant with putrescine compared to brassinolide only under normal irrigation and severe stress (irrigation interval $\times$ growth regulator interaction). This superiority was more pronounced under normal irrigation (Figure 1). The decrement in the number of grains per plant under water limitation was associated with the reduced number of grains per capitol (Table 3 ). Ghassemi-Golezani and Afkhami (2018) found that the main reason for a decline in the number of grains per plant under water deficit was the reduction of green cover percentage and plant biomass. Reduction in the number of grains per plant due to water deficit is also reported in chickpea (Ghassemi-Golezani et al. 2008), sesame (Eskandari et al. 2009), and milk thistle (Ghassemi-Golezani et al. 2017). This reduction may be caused by excessive loss of leaves at reproductive stages as reported in sunflower (Rauf 2008).

Increasing irrigation intervals decreased 1,000-seeds weight, but there was no significant difference among normal irrigation, mild stress, and moderate stress (Table 3). Foliar application of both growth regulators increased 1,000-seeds weight (Table 3). Increasing grain weight by foliar spray of growth regulators could be the result of from prolonged leaf area duration and, hence, a longer grain filling period. Environmental stresses such as water shortage, especially during grain filling can reduce photosynthesis and remobilization of stored materials and hence, grain filling duration (Sadeghipour 2008). Water stress generally accelerates leaf senescence and shortens grain filling duration (Davis et al. 1999). Also, water deficit reduced 1,000-seeds weight and grain yield by shortening the grain filling period of wheat (Gooding et al. 2003). Reduced grain filling occurs due to decreased segregation of assimilates and activities of enzymes involved in sucrose and starch biosynthesis (Srivastava \& Suprasanna 2015). Application of brassinosteroids also

$\mathrm{T}$ a b 1 e 3

Means of plant biomass, number of grains per capitol and 1,000-seeds weight for different irrigation intervals and foliar spray of growth regulators

\begin{tabular}{|c|c|c|c|}
\hline Treatment & Plant biomass $\left[\mathrm{g} / \mathrm{m}^{2}\right]$ & Grains per capitol & 1,000 -seeds weight $[\mathrm{g}]$ \\
\hline \multicolumn{4}{|c|}{ Irrigation } \\
\hline $\mathrm{I}_{1}$ & $765.1^{\mathrm{a}}$ & $32.9^{\mathrm{a}}$ & $27.9^{\mathrm{ab}}$ \\
\hline $\mathrm{I}_{2}$ & $655.4^{\mathrm{b}}$ & $27.8^{\mathrm{b}}$ & $28.4^{\mathrm{a}}$ \\
\hline $\mathrm{I}_{3}$ & $615.5^{\mathrm{c}}$ & $27.4^{b}$ & $28.1^{\mathrm{ab}}$ \\
\hline $\mathrm{I}_{4}$ & $488.6^{\mathrm{d}}$ & $26.4^{\mathrm{b}}$ & $26.6^{\mathrm{b}}$ \\
\hline \multicolumn{4}{|c|}{ Foliar spray } \\
\hline Water (control) & $580.0^{\mathrm{b}}$ & $23.1^{\mathrm{b}}$ & $27.08^{b}$ \\
\hline Putrescine & $672.0^{\mathrm{a}}$ & $32.8^{\mathrm{a}}$ & $28.25^{\mathrm{a}}$ \\
\hline 24-epibrassinolide & $641.5^{\mathrm{a}}$ & $30.1^{\mathrm{a}}$ & $27.95^{\mathrm{a}}$ \\
\hline
\end{tabular}

Different letters in each column indicate significant difference at $p \leq 0.05$ (Duncan test)

$\mathrm{I}_{1}, \mathrm{I}_{2}, \mathrm{I}_{3}, \mathrm{I}_{4}$ - irrigation after 70, 100, 130 and 160-mm evaporation from class A pan, respectively 
increased grain weight and; consequently, eventually grain yield in chickpea (Shahid et al. 2011). Emam and Doghezloo (2015), reported that water stress has reduced grain weight and foliar application of brassinosteroids has increased grain weight in wheat cultivars under different irrigation variants.

Reduction in grain yield under water stress (Figure 2) can be attributed to reduced grains per capitol (Table 3), grains per plant (Figure 1) and 1,000 -seeds weight (Table 3 ). There is a significant positive correlation of 1,000-seeds weight and grain yield of safflower (Yari \& Keshtakar 2016). Water limitation during flowering leads to flower abortion and poor seed set, which can potentially reduce grain yield of chickpea per unit area (Fang et al. 2009). The growth regulators, especially putrescine, enhanced the grain yield of safflower under normal and limited irrigations, with a greater impact in normal watering (Figure 2). Zafari et al. (2017), reported that safflower yield was reduced by water deficit, but it was improved by 24-epibrassinolide treatment through enhancing plant metabolism and stress tolerance (Talaat \& Shawki 2013). Application of putrescine on drought-stressed wheat plants increases the number of spikes, spike weight; and grain yield (Gupta et al. 2012). Polyamines such as putrescine have antioxidant properties, which in-

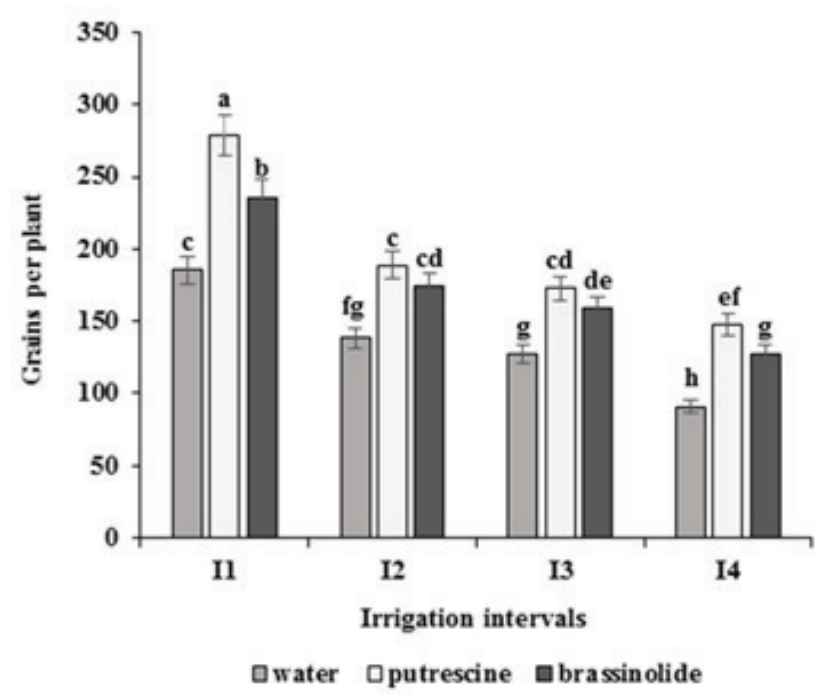

Figure 1. Means of safflower grains per plant for interaction of irrigation intervals $\times$ growth regulators

- I1, I2, I3 and I4 - irrigation after 70, 100, 130 and 160-mm evaporation, respectively,

- Different letters indicate a significant difference at $p \leq 0.05$ (Duncan test). hibit membrane lipid peroxidation and reduce the production of free radicals. It also prevents the synthesis of ethylene and delays the aging of the plant, thereby increasing the effective period of grain filling and grain yield (Bregoli et al. 2002).

Foliar application of the growth regulators had a significantly positive impact on the harvest index of safflower under all irrigation intervals. However, putrescine was more effective than 24-epibrasinolide, particularly under normal irrigation (Figure $3)$. This reflects the higher impact of growth regulators on grain yield (Figure 2) than on plant biomass (Table 3). The high harvest index is related to the formation of more grains per plant and allocation of more assimilates to the grains, which is strongly supported by a previous report on beans (Munoz-Pera et al. 2006). Increasing irrigation intervals caused a decline in bean harvest index, while foliar application of 24-epibrasinolide enhanced it (Mohammadi et al. 2018b). This improvement in harvest index could be resulted from the higher effect of 24-epibrasinolide on grain yield, compared to plant biomass.

The oil percentage of safflower grains was decreased with decreasing water availability (Figure 4). The oil content was mainly controlled by the genetic characteristics of a cultivar, but photosynthetic

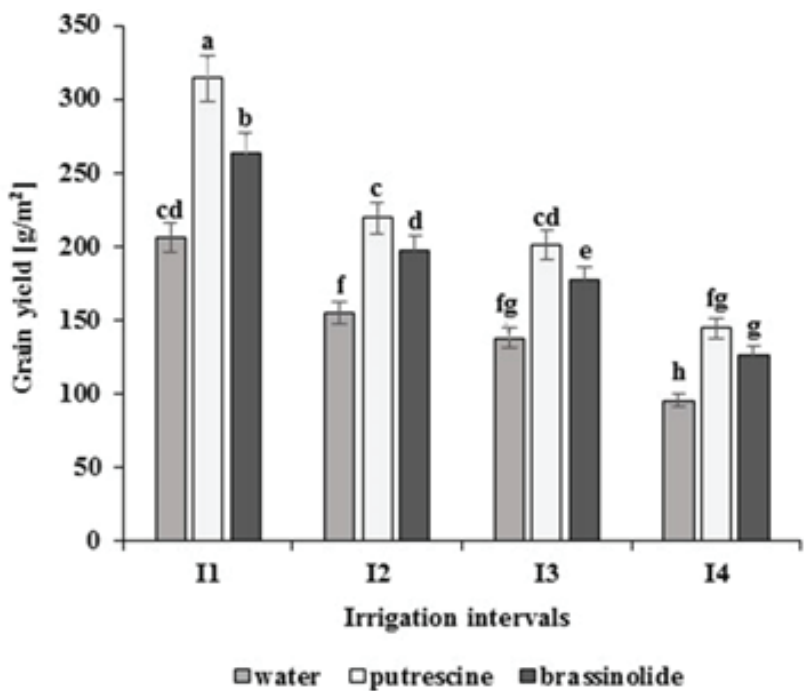

Figure 2. Means of grain yield for interaction of irrigation intervals $\times$ growth regulators in safflower

- I1, I2, I3 and I4 - irrigation after 70, 100, 130 and 160-mm evaporation, respectively,

- Different letters indicate a significant difference at $p \leq 0.05$ (Duncan test). 


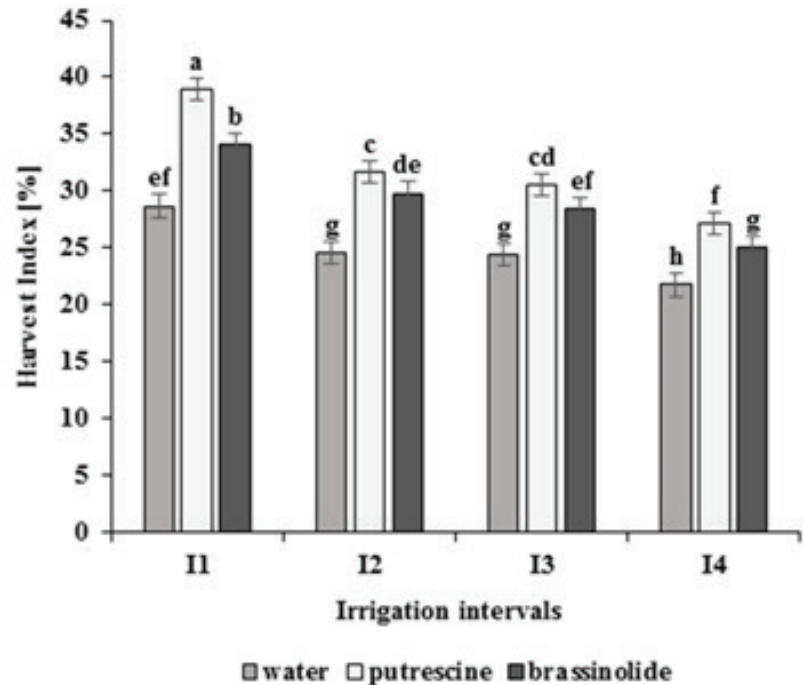

Figure 3. Means of harvest index for interaction of irrigation intervals $\times$ growth regulators in safflower

- I1, I2, I3 and I4 - irrigation after 70, 100, 130 and 160-mm evaporation, respectively,

- Different letters indicate a significant difference at $p \leq 0.05$ (Duncan test).

products as the source of oil synthesis can be greatly reduced by water deficit. This might be also explained by decreased availability of carbohydrates for oil synthesis under drought stress (Ashrafi \& Razmju 2014). Mohammadi et al. (2018a) reported that a decline in oil percentage of safflower grains in water deficit conditions is related to the reduction of the seeds' capacity for oil accumulation and

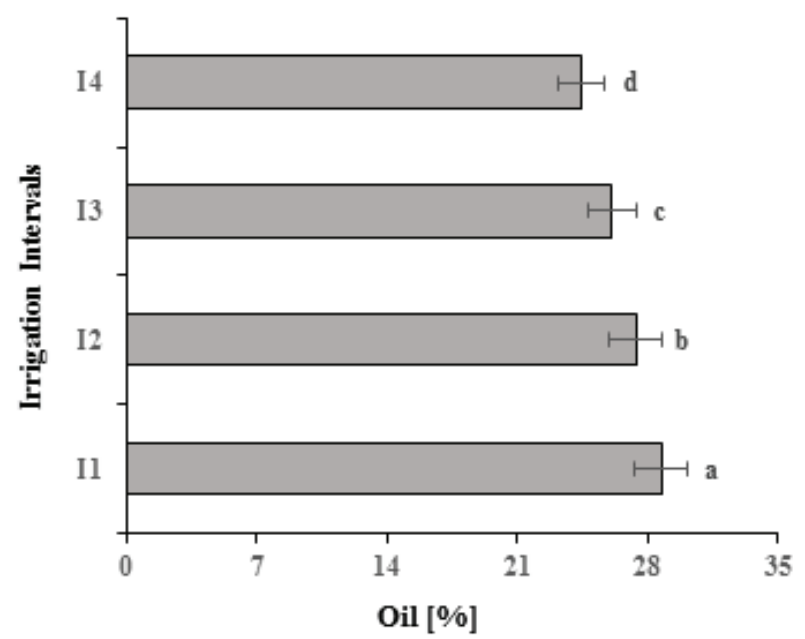

Figure 4. Changes in mean oil percentage of safflower seeds under different irrigation intervals

- I1, I2, I3 and I4 - irrigation after 70, 100, 130 and 160-mm evaporation, respectively,

- Different letters indicate a significant difference at $p \leq 0.05$ (Duncan test).

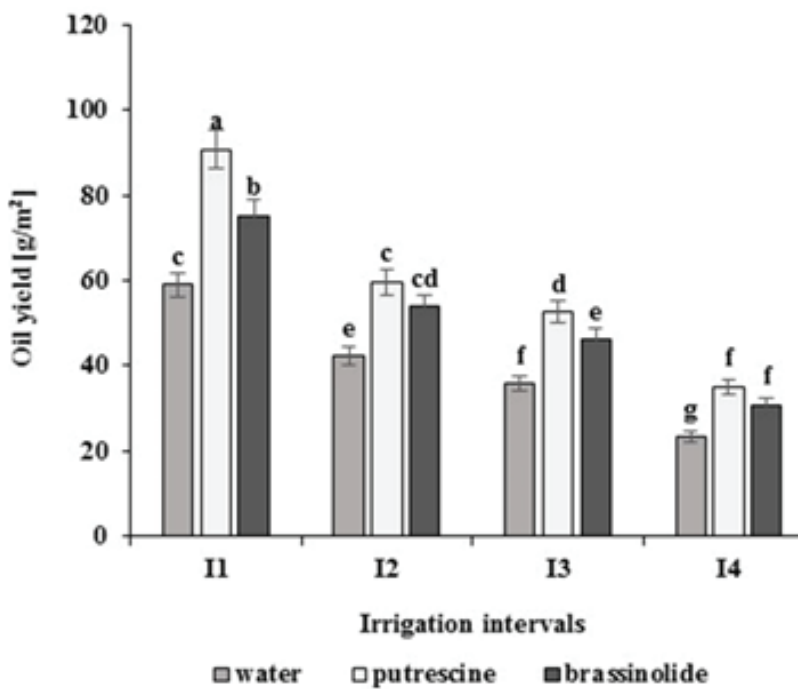

Figure 5. Means of safflower oil yield for interaction of irrigation intervals $\times$ growth regulators

- I1, I2, I3 and I4 - irrigation after 70, 100, 130 and 160-mm evaporation, respectively,

- Different letters indicate a significant difference at $p \leq 0.05$ (Duncan test).

oxidation of the oil. Increasing irrigation intervals in maize also decreased the percentage of seed oil (Ghassemi-Golezani et al. 2016).

A significant reduction in oil yield of safflower with increasing irrigation interval was the result of decrements in grain yield (Figure 2) and oil percentage (Figure 4), which was also supported by previous reports on this crop (Ghassemi-Golezani \& Afkhami 2018). Drought stress severely limits the growth and development of plants by affecting different metabolic processes such as $\mathrm{CO}_{2}$ assimilation and oil and protein synthesis (Nasirkhan et al. 2007). Esmaeilian et al. (2012), reported that water stress at the grain filling stage of sunflower caused a decrease in oil content. There is a strong positive correlation between oil yield and grain yield of safflower (Omidy Tabrizi et al. 2000).

Foliar spray of putrescine was the superior treatment on increasing oil yield of safflower under normal and limited irrigations, followed by 24 -epibrassinolide. This advantage was greater under normal irrigation, compared to other irrigation intervals (Figure 5). This superiority in oil yield was directly related to the positive impacts of 24-epibrassinolide and particularly putrescine on grain yield per unit area (Figure 2), since oil percentage was not affected by these growth regulators (Table 2). 


\section{CONCLUSIONS}

Water limitation significantly reduced plant biomass, grains per capitol, grains per plant, 1,000-grain weight, grain yield, and harvest index of safflower, which were improved by foliar spray of growth regulators. Oil percentage and yield of safflower grains were also decreased with decreasing water supply. Application of putrescine and 24-epibrassinolide noticeably enhanced grains per plant, grain yield and harvest index, leading to an improvement in oil yield per unit area under all irrigation intervals, especially under normal irrigation. Foliar spray of putrescine was the superior treatment for improving these traits. Therefore, application of 24-epibrassinolide and especially putrescine can considerably enhance safflower plant productivity under normal and limited irrigations.

\section{REFERENCES}

Ananthi, M., Sasthri, G. and Srimathi, P. (2013). Integrated seed and crop management increasing productivity of green gram cv. CO6. International Journal of Science Research, 2, 37-38. DOI:10.36106/ijsr.

Anjum, S.A., Wang, L.C., Farooq, M., Hussain, M., Xue, L.L. and Zou, C.M. (2011). Brassinolide application improves the drought tolerance in maize through modulation of enzymatic antioxidants and leaf gas exchange. Journal of Agriculture and Crop Science, 197, 177-185. DOI:10.1111/ j.1439-037X.2010. 00459.x

Ashrafi, E. and Razmju, J. (2014). Effect of seed hydropriming and irrigation regimes on grain, biological yield, harvest index, oil and protein content of safflower (Carthamus tinctorius L.) cultivars. Journals of Agricultural Research and Natural Resources Center of Khorasan Razavi, 2, 61-68. DOI:10.22092/aj.2014.101206.

Bajguz, A. and Piotrowska-Niczyporuk, A. (2014). Interactive effect of brassinosteroids and cytokinins on growth, chlorophyll, monosaccharide and protein content in the green alga Chlorella vulgaris L.). Plant Physiology and Biochemistry, 80, 176-183. DOI:10.1016/j. plaphy.2014.04.009.

Bajguz, A. and Hayat, S. (2009). Effects of brassinosteroids on the plant response to environmental stresses. Plant Physiology and Biochemistry, 47, 1-8. DOI:10.1016/j. plaphy.2008.10.002.

Bregoli, A.M., Scaramagli, S., Costa, G., Sabatini, E., Ziosi, V., Biondi, S. and Torrigiani, P. (2002). Peach (Prunus persica L.) fruit ripening: amino ethoxy vinyl glycine (AVG) and exogenous polyamines affect ethylene emission and flesh firmness. Physiology Plantarum, 114, 472-481. DOI:10.1034/j.1399-3054.2002. 1140317.x.

Davis, S., Turner, N.C., Siddique, KH.M., Leport, L. and Plummer, J. (1999). Seed growth of Desi and Kabuli chickpea (Cicer arietinum L.) in a short season Mediterraneantype environment. Australian Journal of Experimental
Agriculture, 39, 181 -188. DOI:10.1071/Ea98134.

Dehghan, M., Baluchi, H., Yodavi, A.R. and Safikhani, F. (2017). Effect of foliar application of brassinolide on grain yield and yield components of bread wheat (Triticum aestivum L.) cv. Sirvan under terminal drought stress conditions. Iranian Journal of Crop Sciences, 19, 40-56.

Emadi, M.S., Hasibi, P. and Azimi, A.R. (2013). Effect of foliar application of putrescine and nutrients on grain yield and quality of two wheat cultivars. Iranian Journal of Crop Sciences, 15, 247-261.

Emam, Y. Jahani and Doghezloo, M. (2017). Effect of salicylic acid and brassinosteroid on alleviation of water stress in two wheat cultivars. Journal of Crop Production and Processing, 7(1), 127-139. DOI:10.18869/acadpub.jcpp.7.1.127.

Eskandari, H., Zehtab-Salmasi, S., Ghassemi-Golezani, K. and Gharineh, M.H. (2009). Effects of water limitation on grain and oil yields of sesame cultivars. Journal of Food Agriculture and Environmental Science, 7, 339-342.

Esmaeilian, Y., Sirousmehr, A.R., Asghripour, M.R. and Amiri, E. (2012). Comparison of sole and combined nutrient application on yield and biochemical composition of sunflower under water stress. International Journal of Applied Science and Technology, 2, 214-220.

Fang, X., Turner, N.C., Yan, G., Li, F. and Siddique, KH.M. (2009). Flower numbers, pod production, pollen viability, and pistil function are reduced and flower and pod abortion increased in chickpea (Cicer arietinum L.) under terminal drought. Journal of Experimental Botany, 61, 335-345. DOI:10.1093/jxb/erp307.

Fuji, S., Hirai, K. and Saka, H. (1991). Growth-regulating action of brassinolide in rice plants. In Cutler, H.G., Yokota, T. and Adam, G. (Eds.) Brassinosteroids (Chemistry, Bioactivity, and Applications), vol. 474, ACS Symposium Series, American Chemical Society, pp. 306-311. DOI:10.1021/ bk-1991-0474.ch027.

Ghassemi-Golezani, K. and Afkhami, N. (2018). Safflower productivity and oil yield affected by water limitation and nano fertilizers. Journal of Biodiversity and Environmental Sciences, 12, 425-431.

Ghassemi-Golezani, K., Dalil, B., Muhammadi-Nasab, A.D. and Zehtab-Salmasi, S. (2008). The response of chickpea cultivars to field water deficit. Notulae Botanicae Horti Agrobotanici Cluj-Napoca, 36, 25-28. DOI:10.15835/ nbha36185.

Ghassemi-Golezani, K., Ghassemi, S. and Yaghoubian, I. (2017). Improving oil and flavonoid contents of milk thistle under water stress by salicylic acid. Advances in Horticultural Science, 31, 19-23. DOI:10.13128/ahs-20721.

Ghassemi-Golezani, K., Heydari, Sh. and Dalil, B. (2016). Changes in seed oil and protein contents of maize cultivars at different positions on the ear in response to water limitation. Acta Agriculturae Slovenica, 107, 311-319. DOI:10.14720/aas.2016.107.2.05.

Gilbert, J. (2008). International safflower production - an overview. 7th International Safflower Conference, Wagga Wagga, New South Wales, Australia, 3-6 November, pp. $1-7$.

Gooding, M., Ellis, R., Shewry, P. and Schofield, J. (2003). Effects of restricted water availability and increased temperature on the grain filling, drying and quality of winter wheat. Journal of Cereal Science, 37, 295-309. DOI:10.1006/jcrs.2002.0501.

Gupta, S., Agarwal, V.P. and Gupta, N.K. (2012). Efficacy of putrescine and benzyl adenine on photosynthesis and productivity in relation to drought tolerance in wheat (Triticum aestivum L.). Physiology and Molecular Biology of Plants, 18, 331-336. DOI:10.1007/s12298-012-0123-9. 
Gupta, K., Dey, A. and Gupta, B. (2013). Plant polyamines in abiotic stress responses. Acta Physiologiae Plantarum, 35, 2015-2036. DOI:10.1007/s11738-013-1239-4.

Kandil, M.M., El-Saady, M.B., Mona, H.M., Afaf, M.H. and Iman, M.E. (2011). Effect of putrescine and uniconazole treatments on flower characters and photosynthetic pigments of Chrysanthemum indicum L. plant. The Journal of American Science, 7, 399-408.

Krouma, A., Fujimura, T. and Abdely, C. (2015). Growth, photosynthetic activity and water relations three Tunsian chickpea genotypes (Cicer arietinum L.) subjected to a progressive water deficit stress. International Research Journal, 5, 206-214.

Li, Z., Peng, Y., Zhang, X.Q., Pan, M.H, Ma, X. and Huang, L.K. (2014). Exogenous spermidine improves water stress tolerance of white clover (Trifolium repens L.) involved in antioxidant defense, gene expression and proline metabolism. Plant Omics, 19, 517-526. DOI:10.3390/ molecules191118003.

Mohammadi, M., Ghassemi-Golezani, K., Chaichi, M.R. and Safikhani, S. (2018a). Seed oil accumulation and yield of safflower (Carthamus tinctorius L.) affected by water supply and harvest time. Agronomy Journal, 110, 586-593. DOI:10.2134/agronj2017.06.0365.

Mohammadi, M., Tavakoli, A., Puryusov, M. and Mohseni Fard, A. (2018b). Effect of 24-epibrasinolide on bean seed growth and yield under optimal irrigation and drought stress conditions. Journal of Agriculture, 20, 595-608. DOI:10.22059/JCI.2018.249057.1913.

Munoz-Pera, C.G. Teran, H. Allen, R.G.,Wright, J.L. Westermann, D.T. and Singh, S.P. (2006). Selection for drought resistance in dry bean landraces and cultivars. Crop Science, 46, 2111-2120. DOI:10.2135/ cropsci2006.01.0029.

Nasirkhan, M., Siddiqui, H., Masroor, M., Khan, A. and Naeem, M. (2007). Salinity induced changes in growth, enzyme activities, photosynthesis, proline accumulation and yield in linseed genotypes. World Journal of Agricultural Science, 3, 685-695.

Omidy-Tabrizi, A.H., Ahmadi, M.R, Shahsavari, M.R. and Karimi, S. (2000). Study of grain and oil yields stability in some winter safflower cultivars and lines. Seed and Plant Production Journal, 16(2), 130-145.

Ozdemir, F., Bor, M., Demiral, T. and Turkan, I. (2004). Effects of 24-epibrassinolide on seed germination, seedling growth, lipid peroxidation, proline content and anti-oxidative system of rice (Oriza sativa L.) under salinity stress. Plant Growth Regulation, 42, 203-211. DOI:10.1023/ B:GROW.0000026509.25995.13.

Ozturk, A. (1999). The effect of drought on the growth and yield of winter wheat. Turkish Journal of Agriculture and Forestry, 23, 531-540.

Rao, S.S.R., Vardhini, B.V., Sujatha, E. and Anuradha, S. (2002). Brassinosteroids: A new class of phytohormones. Current Science, 82, 1239-1245.

Rauf, S. (2008). Breeding sunflower (Helianthus annuus L.) for drought tolerance. Communications in Biometry and Crop Science, 3, 29-44.

Sadeghipour, O. (2008). Effect of withholding irrigation at different growth stages on yield and yield components of mung bean (Vigna radiata L.) varieties. Am-Eura's Journal of Agriculture and Environmental Science, 4, 590-594.

Shahid, M., Pervez, M., Balal, R., Mattson, N., Rashid, A., Ahmad, R., Ayyub, C. and Abbas, T. (2011). Brassinosteroid (24-Epibrassinolide) enhances growth and alleviates the deleterious effects induced by salt stress in Pea (Pisum sativum L.). Australian Journal of Crop Science, 5, $500-510$.

Skirycz, A. and Inze, D. (2010). More from less: Plant growth under limited water. Current Opinion in Biotechnology, 21, 197-203. DOI:10.1016/j.copbio.2010.03.002.

Srivastava, A.K. and Suprasanna, P. (2015). Redox regulated mechanisms implications for enhancing plant stress tolerance and crop yield. In Pandey, K. (Ed.) Elucidation of abiotic stress signaling in plants: functional genomics perspectives. New York: Springer, pp. 191-205. DOI: 10.1007/978-1-4939-2211-6 7.

Talaat, N.B. and Shawky, B.T. (2013). 24-Epibrassinolide alleviates salt-induced inhibition of productivity by increasing nutrients and compatible solutes accumulation and enhancing antioxidant system in wheat (Triticum aestivum L.). Acta Physiologiae Plantarum, 35, 729-740. DOI:10.1007/s11738-012-1113-9.

Yari, P. and Keshtkar, A.H. (2016). Correlation between traits and path analysis of safflower grain yield under water stress conditions. Iranian Journal of Field Crops Research, 14, 427-437. DOI:10.22067/gsc.v14i3.42699.

Zafari, M., Ebadi, A., Jahanbakhsh Gadeh-Kahriz, S. and Sedghi, M. (2017). Evaluation of some physiological characteristics of safflower cultivars (Carthamus tinctorius L.) under dehydration and application of brassinosteroids. Journal of Crop Plant Eco-physiology, 11, 743-758.

Zhang, M., Zhai, Z., Tian, X., Duan, L. and Li, Z. (2008). Brassinolide alleviated the adverse effect of water deficits on photosynthesis and the antioxidant of soybean (Glycine max L.). Plant Growth Regulation, 56, 257-264. DOI: 10.1007/s10725-008-9305-4.

Received: March 29, 2021

Accepted: May 25, 2021 